\title{
Lewis-Acid Acceleration of C-N Bond-Forming Reductive Elimination from Heteroarylpalladium Complexes and Catalytic Amidation of Heteroaryl Bromides
}

\author{
Qilong Shen and John F. Hartwig* \\ Department of Chemistry, Yale University, P.O. Box 208107, New Haven, Connecticut 06520-8107, and \\ Department of Chemistry, University of Illinois, Box 58-6, 600 South Mathews Avenue, Urbana, Illinois \\ 61801
}

\section{Supporting Information}

General Methods. Unless otherwise noted, all manipulation were conducted under an inert atmosphere. ${ }^{1} \mathrm{H}$ and ${ }^{13} \mathrm{C}$ NMR spectra were recorded on a Bruker DPX 400 or $500 \mathrm{MHz}$ Spectrometer, and ${ }^{31} \mathrm{P}\left\{{ }^{1} \mathrm{H}\right\} \mathrm{NMR}$ spectra were recorded on a General Electric QE $300 \mathrm{MHz}$ spectrometer with tetramethylsilane or residual protiated solvent as a reference. All ${ }^{31} \mathrm{P}\left\{{ }^{1} \mathrm{H}\right\}$ NMR chemical shifts are reported in parts per million relative to an $85 \% \mathrm{H}_{3} \mathrm{PO}_{4}$ external standard. Chemical shifts downfield of the standard are reported with positive values. Elemental analyses were performed by Atlantic Microlabs Inc., Norcross, GA or Robertson Microlab, Inc., Madison, NJ. GC and GC/MS analyses were conducted with an HP-1 methyl silicone column.

Unless specified otherwise, all reagents were purchased from commercial suppliers and used without further purification. $\left[\mathrm{PdBr}(\mathrm{R})\left(\mathrm{PPh}_{3}\right)_{2}\right]^{1}\left(\mathrm{R}=\mathrm{C}_{5} \mathrm{H}_{4} \mathrm{~N}-\mathrm{C}^{3}, \mathrm{C}_{5} \mathrm{H}_{4} \mathrm{~N}-\mathrm{C}^{4}\right),\left[\mathrm{PdBr}(\mathrm{R})\left(\mathrm{PPh}_{3}\right)\right]_{2}\left(\mathrm{R}=\mathrm{C}_{5} \mathrm{H}_{4} \mathrm{~N}-\mathrm{C}^{3}\right)$, and $[\mathrm{Pd}(\mathrm{DPPBz})(p-\mathrm{Tol})(\mathrm{Br})](4)^{2}$ were prepared by literature procedures. Potassium amides were prepared by the addition of one equivalent of the corresponding amine to a suspension of one equivalent of $\mathrm{KH}$ in benzene. Potassium amidates were prepared by the addition of one equivalent of the corresponding amide to a suspension of one equivalent of KH in THF.

Preparation of Tol-DPPBz. Into to a Schlenk flask was placed $\mathrm{Pd}(\mathrm{OAc})_{2}(110 \mathrm{mg}, 0.500 \mathrm{mmol}), 1$ bromo-2-iodobenzene $(2.83 \mathrm{~g}, 10.0 \mathrm{mmol})$ and di-p-tolphosphine $(2.14 \mathrm{~g}, 10.0 \mathrm{mmol})$. The flask was sealed with a septum and then evacuated and filled with nitrogen three times. Triethyl amine $(7.00 \mathrm{~mL}, 50.0 \mathrm{mmol})$ and acetonitrile $(20.0 \mathrm{~mL})$ was then added. The reaction mixture was stirred for $12 \mathrm{~h}$ at $100{ }^{\circ} \mathrm{C}$. The reaction mixture was allowed to cool to room temperature before filtered through a short plug of Celite. The solvent was evaporated, and the crude product isolated by silica gel chromatography eluting with hexane/ethyl acetate $(95 / 5)$ to give $3.50 \mathrm{~g}(95 \%)$ of the product as a white solid. ${ }^{1} \mathrm{H} \mathrm{NMR}\left(\mathrm{CDCl}_{3}\right) \delta 7.45-7.50(\mathrm{~m}, 1 \mathrm{H})$, 7.05-7.10 (m, $10 \mathrm{H}), 6.65-6.70(\mathrm{~m}, 1 \mathrm{H}) ;{ }^{31} \mathrm{P}\left\{{ }^{1} \mathrm{H}\right\}$ NMR $\left(\mathrm{CD}_{2} \mathrm{Cl}_{2}\right) \delta-6.34(\mathrm{~s})$.

An ether solution of $p$-tolylmagnesium chloride $(100 \mathrm{~mL}, 0.5 \mathrm{M}, 100 \mathrm{mmol})$ was added dropwise to a cold solution $\left(-78{ }^{\circ} \mathrm{C}\right)$ of $\mathrm{Me}_{2} \mathrm{NPCl}_{2}(7.30 \mathrm{~g}, 50.0 \mathrm{mmol})$ and pyridine $(20.0 \mathrm{~mL}, 250 \mathrm{mmol})$ in dry ether. The reaction mixture was stirred for $2 \mathrm{~h}$ at room temperature and heated to reflux for additional $2 \mathrm{hr}$. The solution was cooled to room temperature and $\mathrm{HCl}$ in ether $(30.0 \mathrm{~mL}, 2.00 \mathrm{M}$ in diethyl ether) was added dropwise. The mixture was stirred for additional $10 \mathrm{hr}$ at room temperature. The mixture consisted two layers. The upper layer was collected and concentrated under reduced pressure to give $4.50 \mathrm{~g}$ of the crude $(p \text {-tolyl })_{2} \mathrm{PCl}$. The crude product was used directly without further purification.

A solution of 1-bromo-2-(di-p-tolylphenyl)phosphinobenzene $3.69 \mathrm{~g}, 10.0 \mathrm{mmol})$ in THF $(50.0 \mathrm{~mL})$ was cooled to $-78{ }^{\circ} \mathrm{C}$ and $n \mathrm{BuLi}(7.00 \mathrm{~mL}, 1.60 \mathrm{M}, 11.2 \mathrm{mmol})$ was added dropwise. The solution was stirred at $78{ }^{\circ} \mathrm{C}$ for $1 \mathrm{hr}$ and chloro-di-p-tolylphosphine $(2.80 \mathrm{~g}, 11.0 \mathrm{mmol})$ in 10.0 diethyl ether was added dropwise. The solution was allowed to warm to room temperature and stir for $2 \mathrm{~h} . \mathrm{CH}_{2} \mathrm{Cl}_{2}(50.0 \mathrm{~mL})$ was then added to the solution. The organic layer was washed with water and saturated sodium chloride and then dried over magnesium sulfate. The solvent was removed under reduced pressure, and the residue was purified by silica gel chromatography, eluting with hexane/ethyl acetate (80/20) to give $3.50 \mathrm{~g}(70 \%)$ of the desired TolDPPBz as a white solid. ${ }^{1} \mathrm{H}$ NMR $\left(\mathrm{CD}_{2} \mathrm{Cl}_{2}\right) \delta 7.21(\mathrm{dd}, J=6.0,3.0 \mathrm{~Hz}, 2 \mathrm{H})$, 6.96-7.05 (m, $\left.18 \mathrm{H}\right), 2.29(\mathrm{~s}, 12$ $\mathrm{H}) ;{ }^{31} \mathrm{P}\left\{{ }^{1} \mathrm{H}\right\} \mathrm{NMR}\left(\mathrm{CD}_{2} \mathrm{Cl}_{2}\right) \delta$-15.42. Anal. Calcd. For $\mathrm{C}_{34} \mathrm{H}_{32} \mathrm{P}_{2}: \mathrm{C}, 81.26 ; \mathrm{H}, 6.42$. Found: $\mathrm{C}, 81.11 ; \mathrm{H}$, 6.22 . 


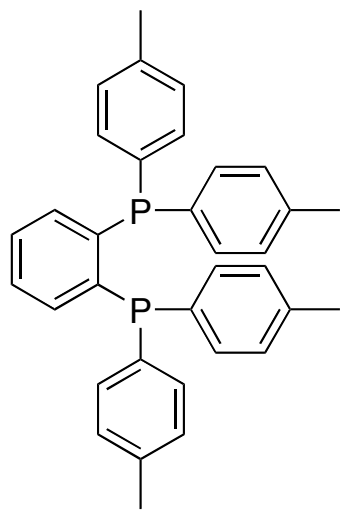

General Procedure for the Synthesis of [Pd(DPPBz)(Ar) $(\mathrm{Br})], \mathrm{Ar}=\mathrm{C}_{5} \mathrm{H}_{4} \mathrm{~N}-\mathrm{C}^{3}, \mathrm{C}_{5} \mathrm{H}_{4} \mathrm{~N}-\mathrm{C}^{4}$. A solution of 1,2-bis(diphenylphosphino)benzene $(97.0 \mathrm{mg}, 0.220 \mathrm{mmol})$ in benzene $(5.00 \mathrm{~mL})$ was added dropwise to a stirred mixture of $\left[\mathrm{Pd}\left(\mathrm{PPh}_{3}\right)_{2}(\mathrm{Ar})(\mathrm{Br})\right](157 \mathrm{mg}, 0.200 \mathrm{mmol})$ in benzene $(10.0 \mathrm{~mL})$. The mixtures changed from cloudy white to clear immediately and became cloudy white again after $5 \mathrm{~min}$. The mixture was stirred at room temperature for $5 \mathrm{~h}$. The white solid was filtered, washed with pentane and used without further purification.

$\left[\mathbf{P d}(\mathbf{D P P B z})\left(\mathbf{C}_{5} \mathbf{H}_{4} \mathbf{N}-\mathbf{C}^{4}\right)(\mathbf{B r})\right]$ (1). The general procedure was followed and gave $101 \mathrm{mg}(84 \%)$ of the

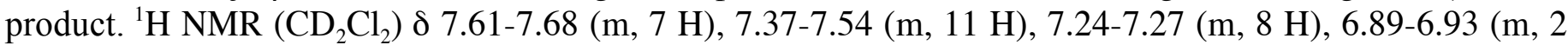
$\mathrm{H}) ;{ }^{31} \mathrm{P}\left\{{ }^{1} \mathrm{H}\right\}$ NMR $\left(\mathrm{CD}_{2} \mathrm{Cl}_{2}\right) \delta 54.2(\mathrm{~d}, J=26 \mathrm{~Hz}), 44.7(\mathrm{~d}, J=26 \mathrm{~Hz})$. Anal. Calcd. For $\mathrm{C}_{35} \mathrm{H}_{28} \mathrm{BrNP}_{2} \mathrm{Pd}$ : C, 59.13; H, 3.97; N, 1.97. Found: C, 59.14; H, 3.70; N, 1.84 .

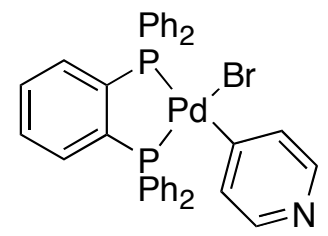

$\left[\mathbf{P d}(\mathbf{D P P B z})\left(\mathbf{C}_{5} \mathbf{H}_{4} \mathbf{N}-\mathbf{C}^{3}\right)(\mathbf{B r})\right]$ (2). The general procedure was followed and gave $146 \mathrm{mg}(90 \%)$ of the product. ${ }^{1} \mathrm{H}$ NMR $\left(\mathrm{CD}_{2} \mathrm{Cl}_{2}\right) \delta$ 7.90-8.06 (m, $\left.1 \mathrm{H}\right)$, 7.84-7.86 (m, $\left.1 \mathrm{H}\right)$, 7.56-7.64 (m, $\left.5 \mathrm{H}\right)$, 7.37-7.56 (m, 11 $\mathrm{H})$, 7.24-7.27 (m, $8 \mathrm{H}), 7.07-7.11(\mathrm{~m}, 1 \mathrm{H}), 6.59(\mathrm{t}, J=4.8 \mathrm{~Hz}, 1 \mathrm{H}) ;{ }^{31} \mathrm{P}\left\{{ }^{1} \mathrm{H}\right\} \mathrm{NMR}(\mathrm{THF}) \delta 55.4(\mathrm{~d}, J=26$ $\mathrm{Hz}), 44.5(\mathrm{~d}, J=26 \mathrm{~Hz})$. Anal. Calcd. For $\mathrm{C}_{35} \mathrm{H}_{28} \mathrm{BrNP}_{2} \mathrm{Pd}: \mathrm{C}, 59.13 ; \mathrm{H}, 3.97 ; \mathrm{N}, 1.97$. Found: C, 58.94; H, $3.91 ; \mathrm{N}, 2.04$.<smiles>Br[Pb]1[Pb]P(c2cccnc2)c2ccccc21</smiles>

$\left[\mathbf{P d}(\mathbf{D T P B z})\left(\mathbf{C}_{5} \mathbf{H}_{4} \mathbf{N}-\mathbf{C}^{4}\right)(\mathbf{B r})\right](\mathbf{5})$. The general procedure was followed and gave $130 \mathrm{mg}(85 \%)$ of the product. ${ }^{1} \mathrm{H}$ NMR $\left(\mathrm{CD}_{2} \mathrm{Cl}_{2}\right) \delta 7.67(\mathrm{t}, J=4.0 \mathrm{~Hz}, 2 \mathrm{H}), 7.56(\mathrm{t}, J=7.0 \mathrm{~Hz}, 1 \mathrm{H}), 7.37-7.47(\mathrm{~m}, 7 \mathrm{H}), 7.11-7.12$ $(\mathrm{m}, 4 \mathrm{H}), 7.08(\mathrm{~d}, J=8.0 \mathrm{~Hz}, 2 \mathrm{H}), 7.05(\mathrm{~d}, J=8.0 \mathrm{~Hz}, 2 \mathrm{H}), 6.99-7.01(\mathrm{~m}, 4 \mathrm{H}), 6.95(\mathrm{td}, J=6.0,2.0 \mathrm{~Hz}, 2$ $\mathrm{H}) ;{ }^{31} \mathrm{P}\left\{{ }^{1} \mathrm{H}\right\} \mathrm{NMR}\left(\mathrm{CD}_{2} \mathrm{Cl}_{2}\right) \delta 53.0(\mathrm{~d}, J=28 \mathrm{~Hz}), 44.1(\mathrm{~d}, J=28 \mathrm{~Hz})$.

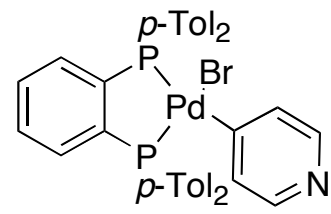


Synthesis of [Pd(DPPBz) $\left.\left(\mathbf{C}_{5} \mathbf{H}_{4} \mathbf{N}-\mathbf{C}^{2}\right)(\mathbf{B r})\right]$ (3). A mixture of 1,2-bis(diphenylphosphino)benzene (188 mg, $0.440 \mathrm{mmol})$ and $\left[\mathrm{PdBr}(\mathrm{R})\left(\mathrm{PPh}_{3}\right)\right]_{2}\left(\mathrm{R}=\mathrm{C}_{5} \mathrm{H}_{4} \mathrm{~N}-\mathrm{C}^{3}\right)(211 \mathrm{mg}, 0.200 \mathrm{mmol})$ in toluene $(20.0 \mathrm{~mL})$ was heated at $90{ }^{\circ} \mathrm{C}$ for $10 \mathrm{~h}$. When the reaction was complete, as indicated by ${ }^{31} \mathrm{P}\left\{{ }^{1} \mathrm{H}\right\}$ NMR spectroscopy, the reaction mixture was filtered through a medium fritted funnel containing Celite. The resulting solution was cooled to room temperature. Addition of pentane led to precipitation of $140 \mathrm{mg}$ (98\% yield) of the product as a white solid. The solid was filtered, washed with pentane and used without further purification. ${ }^{1} \mathrm{H}$ NMR $\left(\mathrm{CD}_{2} \mathrm{Cl}_{2}\right)$ $\delta 8.04(\mathrm{~d}, J=4.8 \mathrm{~Hz}, 1 \mathrm{H}), 7.57-7.62(\mathrm{~m}, 5 \mathrm{H}), 7.44-7.55(\mathrm{~m}, 3 \mathrm{H}), 7.28-7.43(\mathrm{~m}, 12 \mathrm{H}), 7.20-7.24(\mathrm{~m}, 4 \mathrm{H})$, 6.84-6.86 (m, $2 \mathrm{H}), 6.49-6,51(\mathrm{~m}, 1 \mathrm{H}) ;{ }^{31} \mathrm{P}\left\{{ }^{1} \mathrm{H}\right\}$ NMR $\left(\mathrm{CD}_{2} \mathrm{Cl}_{2}\right) \delta 49.4(\mathrm{~d}, J=32 \mathrm{~Hz}), 39.9(\mathrm{~d}, J=32 \mathrm{~Hz})$. Anal. Calcd. For $\mathrm{C}_{35} \mathrm{H}_{28} \mathrm{BrNP}_{2} \mathrm{Pd}$ : C, 59.13; H, 3.97; N, 1.97. Found: C, 59.21; H, 3.84; N, 1.92 .

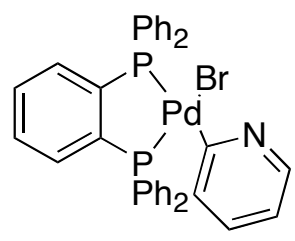

\section{Synthesis of Palladium Amides. Representative Procedure.}

[Pd(DPPBz) $\left.\left(\mathbf{C}_{5} \mathbf{H}_{4} \mathbf{N}-\mathbf{C}^{4}\right)\left(\mathbf{N}\left(\mathbf{C}_{6} \mathbf{H}_{4}-4-t-B u\right)_{2}\right)\right](6) . \mathrm{KN}\left(\mathrm{C}_{6} \mathrm{H}_{4}-4-t-\mathrm{Bu}_{2}(33.6 \mathrm{mg}, 0.110 \mathrm{mmol})\right.$ in $2.0 \mathrm{~mL}$ of THF was added dropwise to a suspension of $\left[\mathrm{Pd}(\mathrm{DPPBz})\left(\mathrm{C}_{5} \mathrm{H}_{4} \mathrm{~N}-\mathrm{C}^{4}\right)(\mathrm{Br})\right](71.2 \mathrm{mg}, 0.100 \mathrm{mmol})$ in $10.0 \mathrm{~mL}$ of THF in a $20 \mathrm{~mL}$ vial. The color of the mixture changed from colorless to deep red immediately. The mixture was allowed to stir for $10 \mathrm{~min}$. When the reaction was complete, as indicated by ${ }^{31} \mathrm{P}\left\{{ }^{1} \mathrm{H}\right\}$ NMR spectroscopy, the deep red solution was filtered through Celite to remove the solid. The solvent was evaporated, and toluene $(1.0 \mathrm{ml})$ was added. The red crystalline product was obtained in $89 \%(81.0 \mathrm{mg})$ yield by layering the toluene solution with pentane and cooling at $-35{ }^{\circ} \mathrm{C} .{ }^{1} \mathrm{H} N M R\left(\mathrm{C}_{6} \mathrm{D}_{6}\right) \delta 8.03-8.06(\mathrm{~m}, 2 \mathrm{H})$, 7.46-7.51 (m, $4 \mathrm{H}), 7.35-7.40(\mathrm{~m}, 8 \mathrm{H}), 7.25-7.28(\mathrm{~m}, 2 \mathrm{H}), 6.89-7.04(\mathrm{~m}, 18 \mathrm{H}), 6.80-6.89(\mathrm{~m}, 2 \mathrm{H}), 1.28$ (s, $18 \mathrm{H}) ;{ }^{31} \mathrm{P}\left\{{ }^{1} \mathrm{H}\right\}$ NMR (THF) $\delta 51.6(\mathrm{~d}, J=25 \mathrm{~Hz}), 37.4(\mathrm{~d}, J=25 \mathrm{~Hz})$. Anal. Calcd. For $\mathrm{C}_{55} \mathrm{H}_{54} \mathrm{~N}_{2} \mathrm{P}_{2} \mathrm{Pd}$ : C, 72.48; H, 5.97; N, 3.07. Found: C, 72.23; H, 5.83; N, 2.96.

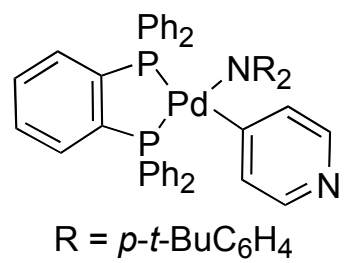

$\left[\mathbf{P d}(\mathrm{DPPBz})\left(\mathbf{C}_{5} \mathbf{H}_{4} \mathbf{N}-\mathbf{C}^{3}\right)\left(\mathbf{N}\left(\mathbf{C}_{6} \mathbf{H}_{4}-4-t-\mathbf{B u}\right)_{2}\right)\right]$ (7). The general procedure was followed, and crystallization from THF layered with pentane at $-35^{\circ} \mathrm{C}$ gave $73 \mathrm{mg}(80 \%)$ of the product. ${ }^{1} \mathrm{H}$ NMR $\left(\mathrm{C}_{6} \mathrm{D}_{6}\right) \delta 8.75-8.77(\mathrm{~m}$, $1 \mathrm{H}), 8.14(\mathrm{dt}, J=4.4,1.2 \mathrm{~Hz}, 1 \mathrm{H}), 7.32-7.48(\mathrm{~m}, 14 \mathrm{H}), 7.12-7.27(\mathrm{~m}, 2 \mathrm{H}), 6.87-7.00(\mathrm{~m}, 15 \mathrm{H}), 6.79-6.81$ (m, $2 \mathrm{H}), 6.45(\mathrm{dt}, J=7.2,1.2 \mathrm{~Hz}, 1 \mathrm{H}), 1.31(\mathrm{~s}, 18 \mathrm{H}) ;{ }^{31} \mathrm{P}\left\{{ }^{1} \mathrm{H}\right\} \mathrm{NMR}(\mathrm{THF}) \delta 52.0(\mathrm{~d}, J=24 \mathrm{~Hz}), 37.7$ (d, $J=24 \mathrm{~Hz}$ ). Anal. Calcd. For $\mathrm{C}_{55} \mathrm{H}_{54} \mathrm{~N}_{2} \mathrm{P}_{2} \mathrm{Pd}: \mathrm{C}, 72.48 ; \mathrm{H}, 5.97 ; \mathrm{N}, 3.07$. Found: C, 72.23; H, 5.88; N, 2.91.

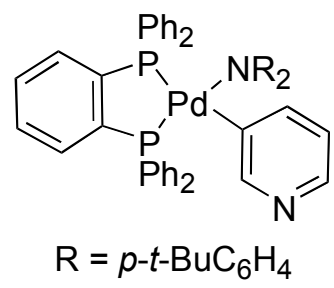


$\left[\mathrm{Pd}(\mathrm{DPPBz})\left(\mathrm{C}_{5} \mathrm{H}_{4} \mathrm{~N}-\mathrm{C}^{2}\right)\left(\mathbf{N}\left(\mathrm{C}_{6} \mathrm{H}_{4}-\mathbf{4}-t-\mathrm{Bu}\right)_{2}\right)\right](\mathbf{8})$. The general procedure was followed, and crystallization from THF layered with pentane at $-35{ }^{\circ} \mathrm{C}$ gave $65 \mathrm{mg}(71 \%)$ of the product. ${ }^{1} \mathrm{H}$ NMR $\left(\mathrm{C}_{6} \mathrm{D}_{6}\right) \delta 8.20(\mathrm{dd}, J=$ $4.8,1.6 \mathrm{~Hz}, 1 \mathrm{H}), 8.70-8.72(\mathrm{~m}, 4 \mathrm{H}), 8.14(\mathrm{dt}, J=8.4 \mathrm{~Hz}, 4 \mathrm{H}), 7.47(\mathrm{dd}, J=8.0,3.4 \mathrm{~Hz}, 1 \mathrm{H}), 7.21-7.36$ $(\mathrm{m}, 6 \mathrm{H}), 7.09(\mathrm{~d}, J=8.4 \mathrm{~Hz}, 4 \mathrm{H}), 6.89-6.96(\mathrm{~m}, 12 \mathrm{H}), 6.81-6.85(\mathrm{~m}, 2 \mathrm{H}), 6.52-6.58(\mathrm{~m}, 1 \mathrm{H}), 6.23(\mathrm{t}, J=$ $6.4 \mathrm{~Hz}, 1 \mathrm{H}), 1.34(\mathrm{~s}, 18 \mathrm{H}) ;{ }^{31} \mathrm{P}\left\{{ }^{1} \mathrm{H}\right\} \mathrm{NMR}(\mathrm{THF}) \delta 44.1(\mathrm{~d}, J=24 \mathrm{~Hz}), 32.2(\mathrm{~d}, J=24 \mathrm{~Hz})$. Anal. Calcd. For $\mathrm{C}_{55} \mathrm{H}_{54} \mathrm{~N}_{2} \mathrm{P}_{2} \mathrm{Pd}$ : C, 72.48; H, 5.97; N, 3.07. Found: C, 72.21; H, 5.88; N, 2.80.

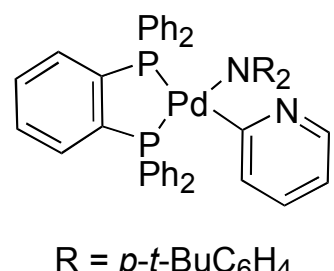

[Pd(DPPBz) $\left.\left(\mathrm{C}_{6} \mathrm{H}_{4}-4-\mathrm{Me}\right)\left(\mathbf{N}\left(\mathrm{C}_{6} \mathrm{H}_{4}-4-t-\mathrm{Bu}\right)_{2}\right)\right]$ (9). The general procedure was followed, and crystallization from toluene layered with pentane at $-35{ }^{\circ} \mathrm{C}$ gave $69 \mathrm{mg}(75 \%)$ of the product. ${ }^{1} \mathrm{H}$ NMR $\left(\mathrm{THF}-d_{8}\right) \delta 7.68-$ $7.72(\mathrm{~m}, 1 \mathrm{H}), 7.51-7.57(\mathrm{~m}, 3 \mathrm{H}), 7.26-7.44(\mathrm{~m}, 15 \mathrm{H}), 7.15-7.20(\mathrm{~m}, 5 \mathrm{H}), 6.86(\mathrm{dt}, J=9.2,2.4 \mathrm{~Hz}, 4 \mathrm{H})$, 6.66-6.69 (m, $2 \mathrm{H}), 6.67(\mathrm{~d}, J=8.8 \mathrm{~Hz}, 4 \mathrm{H}), 6.25(\mathrm{dd}, \mathrm{J}=8.0,2.0 \mathrm{~Hz}, 2 \mathrm{H}), 1.94(\mathrm{~s}, 3 \mathrm{H}), 1.18(\mathrm{~s}, 18 \mathrm{H}) ;{ }^{31} \mathrm{P}$ $\left\{{ }^{1} \mathrm{H}\right\}$ NMR $(\mathrm{THF}) \delta 43.3(\mathrm{~d}, J=22 \mathrm{~Hz}), 28.5(\mathrm{~d}, J=21 \mathrm{~Hz})$. Anal. Calcd. For $\mathrm{C}_{57} \mathrm{H}_{57} \mathrm{NP}_{2} \mathrm{Pd}: \mathrm{C}, 74.06 ; \mathrm{H}$, 6.21; N, 1.52. Found: C, 74.36; H, 5.93; N, 1.46.

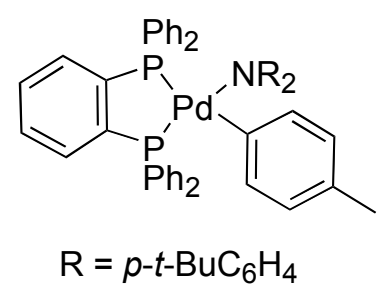

\section{Synthesis of Palladium Amideates.}

Synthesis of $\left[\mathbf{P d}(\mathbf{D T P B z})\left(\mathbf{C}^{4}-\mathbf{C}_{5} \mathbf{H}_{4} \mathbf{N}\right)\left(\mathbf{N}(\mathbf{M e})\left(\mathbf{S O}_{2} \mathbf{P h}\right)\right)\right](\mathbf{1 0}) .\left[\mathrm{Pd}(\mathrm{DTPBz})\left(\mathrm{C}_{5} \mathrm{H}_{4} \mathrm{~N}-\mathrm{C}^{4}\right)(\mathrm{Br})\right](\mathbf{5})(76.8 \mathrm{mg}$, $0.100 \mathrm{mmol})$ and $\mathrm{KN}(\mathrm{Me})\left(\mathrm{SO}_{2} \mathrm{Ph}\right)(35 \mathrm{mg}, 0.167 \mathrm{mmol})$ were placed in a $20 \mathrm{~mL}$ vial. Dichloromethane $(5$ $\mathrm{mL}$ ) was added, and the mixture was stirred at room temperature for $2 \mathrm{~h}$. The solvent was removed in vacuum. THF $(10 \mathrm{~mL})$ was added, and the resulting solution was filtered through Celite. The Celite was washed with $6 \mathrm{~mL}$ of THF, and the volume was reduced under vacuum to $1.0 \mathrm{~mL}$. The white crystalline product was obtained in $72 \%(68.0 \mathrm{mg})$ yield by layering the toluene solution with pentane and cooling at $35{ }^{\circ} \mathrm{C} .{ }^{1} \mathrm{H}$ NMR $\left(\mathrm{C}_{6} \mathrm{D}_{6}\right) \delta 8.14(\mathrm{t}, J=4.0 \mathrm{~Hz}, 2 \mathrm{H}), 7.92(\mathrm{~d}, J=8.0 \mathrm{~Hz}, 2 \mathrm{H}), 7.90(\mathrm{~d}, J=8.0 \mathrm{~Hz}, 2 \mathrm{H}), 7.66$ $(\mathrm{d}, J=8.5 \mathrm{~Hz}, 2 \mathrm{H}), 7.38-7.46(\mathrm{~m}, 7 \mathrm{H}), 7.30-7.32(\mathrm{~m}, 1 \mathrm{H}), 6.99(\mathrm{~d}, J=8.0 \mathrm{~Hz}, 4 \mathrm{H}), 6.81-6.93(\mathrm{~m}, 4 \mathrm{H})$, $6.75(\mathrm{~d}, J=8.0 \mathrm{~Hz}, 4 \mathrm{H}), 2.60(\mathrm{~d}, J=3.0 \mathrm{~Hz}, 3 \mathrm{H}), 1.96(\mathrm{~s}, 6 \mathrm{H}), 1.89(\mathrm{~s}, 6 \mathrm{H}) ;{ }^{31} \mathrm{P}\left\{{ }^{1} \mathrm{H}\right\} \mathrm{NMR}\left(\mathrm{CH}_{2} \mathrm{Cl}_{2}\right) \delta$ $51.2(\mathrm{~d}, J=27 \mathrm{~Hz}), 39.1(\mathrm{~d}, J=27 \mathrm{~Hz})$.

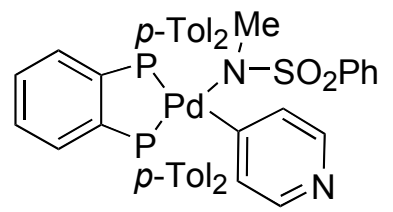

Synthesis of [Pd(DTPBz) $\left(\mathbf{C}^{4}-\mathbf{C}_{5} \mathbf{H}_{4} \mathbf{N}\right)\left(\mathbf{N}(\mathbf{M e})\left(\mathbf{S O}_{2}\right.\right.$ Tol-p $\left.\left.)\right)\right](11)$. [Pd(DTPBz) $\left.\left(\mathrm{C}_{5} \mathrm{H}_{4} \mathrm{~N}-\mathrm{C}^{4}\right)(\mathrm{Br})\right](\mathbf{5})(76.8 \mathrm{mg}$, $0.100 \mathrm{mmol})$ and $\mathrm{KN}(\mathrm{Me})\left(\mathrm{SO}_{2} \mathrm{Tol}-p\right)(35 \mathrm{mg}, 0.167 \mathrm{mmol})$ were placed in a $20 \mathrm{~mL}$ vial. Dichloromethane $(5$ $\mathrm{mL}$ ) was added, and the mixture was stirred at room temperature for $0.5 \mathrm{~h}$. The solvent was removed in vacuum. THF $(10 \mathrm{~mL})$ was added, and the resulting solution was filtered through Celite. The Celite was washed with $6 \mathrm{~mL}$ of THF, and the volume was reduced under vacuum to $1.0 \mathrm{~mL}$. The white crystalline 
product was obtained in $85 \%(74.0 \mathrm{mg})$ yield by layering the THF solution with pentane and cooling at $35{ }^{\circ} \mathrm{C} .{ }^{1} \mathrm{H}$ NMR $\left(\mathrm{C}_{6} \mathrm{D}_{6}\right) \delta 8.32(\mathrm{t}, J=4.4 \mathrm{~Hz}, 2 \mathrm{H}), 8.11(\mathrm{~d}, J=8.0 \mathrm{~Hz}, 2 \mathrm{H}), 8.08(\mathrm{~d}, J=8.0 \mathrm{~Hz}, 2 \mathrm{H}), 7.73$ $(\mathrm{d}, J=8.4 \mathrm{~Hz}, 2 \mathrm{H}), 7.59-7.62(\mathrm{~m}, 3 \mathrm{H}), 7.58(\mathrm{~d}, J=8.0 \mathrm{~Hz}, 2 \mathrm{H}), 7.55(\mathrm{~d}, J=8.0 \mathrm{~Hz}, 2 \mathrm{H}), 7.47(\mathrm{t}, J=7.6$ $\mathrm{Hz}, 1 \mathrm{H}), 7.16(\mathrm{~d}, J=6.8 \mathrm{~Hz}, 4 \mathrm{H}), 6.94-6.99(\mathrm{~m}, 2 \mathrm{H}), 6.90(\mathrm{~d}, J=6.4 \mathrm{~Hz}, 4 \mathrm{H}), 6.89(\mathrm{~d}, J=7.2 \mathrm{~Hz}, 2 \mathrm{H})$, $2.60(\mathrm{~d}, J=2.5 \mathrm{~Hz}, 3 \mathrm{H}), 1.96(\mathrm{~s}, 6 \mathrm{H}), 1.89(\mathrm{~s}, 6 \mathrm{H}), 1.85(\mathrm{~s}, 3 \mathrm{H}) ;{ }^{31} \mathrm{P}\left\{{ }^{1} \mathrm{H}\right\} \mathrm{NMR}\left(\mathrm{CH}_{2} \mathrm{Cl}_{2}\right) \delta 51.2(\mathrm{~d}, J=27$ $\mathrm{Hz}), 39.1(\mathrm{~d}, J=27 \mathrm{~Hz})$. Anal. Calcd. For $\mathrm{C}_{47} \mathrm{H}_{46} \mathrm{BN}_{2} \mathrm{O}_{2} \mathrm{P}_{2} \mathrm{PdS}: \mathrm{C}, 64.79 ; \mathrm{H}, 5.32 ; \mathrm{N}, 3.22$. Found: C, 64.85; $\mathrm{H}, 5.64 ; \mathrm{N}, 2.92$.

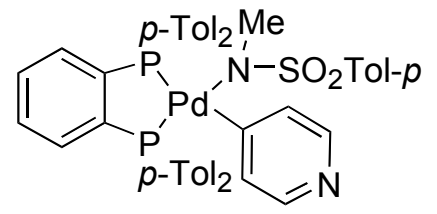

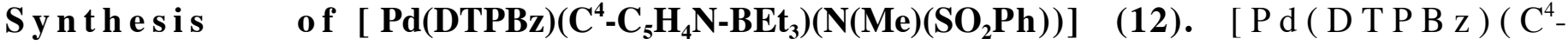
$\left.\left.\mathrm{C}_{5} \mathrm{H}_{4} \mathrm{~N}\right)\left(\mathrm{N}(\mathrm{Me})\left(\mathrm{SO}_{2} \mathrm{Ph}\right)\right)\right](77 \mathrm{mg}, 0.10 \mathrm{mmol})$ was dissolved in $3 \mathrm{~mL}$ of THF. A $1.0 \mathrm{M}$ solution of triethylborane in hexane $(100 \mu \mathrm{L})$ was added. The color of the solution gradually changed from pale yellow to pale pink. After $0.5 \mathrm{~h}$, the solution was filtered through a short plug of Celite, and the volume was reduced under vacuum to $1.0 \mathrm{~mL}$. The white crystalline product was obtained in $80 \%(66.0 \mathrm{mg})$ yield by layering the THF solution with pentane and cooling at $-35{ }^{\circ} \mathrm{C} .{ }^{1} \mathrm{H} \mathrm{NMR}\left(\mathrm{C}_{6} \mathrm{D}_{6}\right) \delta 7.87(\mathrm{~d}, J=8.0 \mathrm{~Hz}, 2 \mathrm{H}), 7.84(\mathrm{~d}, J=8.0$ $\mathrm{Hz}, 2 \mathrm{H}), 7.70(\mathrm{~d}, J=4.5 \mathrm{~Hz}, 2 \mathrm{H}), 7.61(\mathrm{~d}, J=7.0 \mathrm{~Hz}, 2 \mathrm{H}), 7.42(\mathrm{t}, J=6.5 \mathrm{~Hz}, 2 \mathrm{H}), 7.47-7.55(\mathrm{~m}, 1 \mathrm{H})$, $7.37(\mathrm{~d}, J=8.0 \mathrm{~Hz}, 2 \mathrm{H}), 7.34(\mathrm{~d}, J=8.0 \mathrm{~Hz}, 2 \mathrm{H}), 7.22-7.25(\mathrm{~m}, 1 \mathrm{H}), 6.96-6.99(\mathrm{~m}, 2 \mathrm{H}), 6.97(\mathrm{~d}, J=7.5$ $\mathrm{Hz}, 4 \mathrm{H}), 6.88(\mathrm{t}, J=7.5 \mathrm{~Hz}, 1 \mathrm{H}), 6.78-6.85(\mathrm{~m}, 6 \mathrm{H}), 2.41(\mathrm{~d}, J=3.0 \mathrm{~Hz}, 3 \mathrm{H}), 1.93(\mathrm{~s}, 6 \mathrm{H}), 1.91(\mathrm{~s}, 6 \mathrm{H})$, 1.09 (t, $J=7.5 \mathrm{~Hz}, 9 \mathrm{H}), 0.87(\mathrm{q}, J=7.5 \mathrm{~Hz}, 6 \mathrm{H}) ;{ }^{31} \mathrm{P}\left\{{ }^{1} \mathrm{H}\right\} \mathrm{NMR}(\mathrm{THF}) \delta 50.0(\mathrm{~d}, J=27 \mathrm{~Hz}), 36.7(\mathrm{~d}, J=$ $27 \mathrm{~Hz}) .{ }^{11} \mathrm{~B}$ NMR $\left(\mathrm{C}_{6} \mathrm{D}_{6}\right) \delta$ 1.0. Anal. Calcd. For $\mathrm{C}_{52} \mathrm{H}_{59} \mathrm{BN}_{2} \mathrm{O}_{2} \mathrm{P}_{2} \mathrm{PdS}: \mathrm{C}, 65.38 ; \mathrm{H}, 6.23 ; \mathrm{N}, 2.93$. Found: C, $65.55 ; \mathrm{H}, 6.51 ; \mathrm{N}, 2.71$.

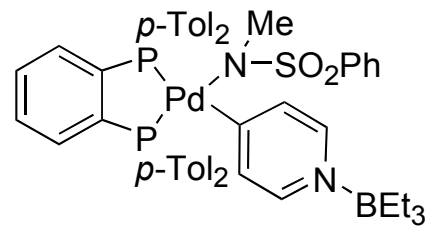

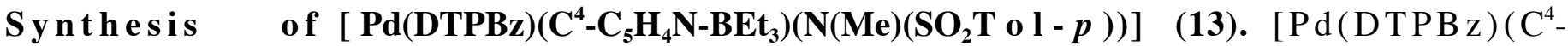
$\left.\left.\mathrm{C}_{5} \mathrm{H}_{4} \mathrm{~N}\right)\left(\mathrm{N}(\mathrm{Me})\left(\mathrm{SO}_{2} \mathrm{Tol}-p\right)\right)\right](87 \mathrm{mg}, 0.10 \mathrm{mmol})$ was dissolved in $3 \mathrm{~mL}$ of THF. A $1.0 \mathrm{M}$ solution of triethylborane in hexane $(100 \mu \mathrm{L})$ was added. The color of the solution gradually changed from pale yellow to pale pink. After $0.5 \mathrm{~h}$, the solution was filtered through a short plug of Celite, and the volume was reduced under vacuum to $1.0 \mathrm{~mL}$. The white crystalline product was obtained in $89 \%(81.0 \mathrm{mg})$ yield by layering the THF solution with pentane and cooling at $-35{ }^{\circ} \mathrm{C} .{ }^{1} \mathrm{H}$ NMR $\left(\mathrm{C}_{6} \mathrm{D}_{6}\right) \delta 7.98(\mathrm{~d}, J=8.5 \mathrm{~Hz}, 2 \mathrm{H}), 7.96(\mathrm{~d}, J=8.0$ $\mathrm{Hz}, 2 \mathrm{H}), 7.80(\mathrm{dd}, J=6.0,2.0 \mathrm{~Hz}, 2 \mathrm{H}), 7.64(\mathrm{~d}, J=8.5 \mathrm{~Hz}, 2 \mathrm{H}), 7.54(\mathrm{t}, J=6.0 \mathrm{~Hz}, 2 \mathrm{H}), 7.47-7.55(\mathrm{~m}, 2$ H), $7.48(\mathrm{~d}, J=8.0 \mathrm{~Hz}, 2 \mathrm{H}), 7.46(\mathrm{~d}, J=8.0 \mathrm{~Hz}, 2 \mathrm{H}), 7.34-7.38(\mathrm{~m}, 1 \mathrm{H}), 7.09$ (dd, $J=8.0,1.5 \mathrm{~Hz}, 4 \mathrm{H})$, $6.94(\mathrm{dd}, J=4.5,3.0 \mathrm{~Hz}, 1 \mathrm{H}), 6.86-6.92(\mathrm{~m}, 6 \mathrm{H}), 2.53(\mathrm{~d}, J=3.0 \mathrm{~Hz}, 3 \mathrm{H}), 2.02$ (s, $6 \mathrm{H}), 1.99$ (s, $6 \mathrm{H}), 1.98$ $(\mathrm{s}, 3 \mathrm{H}), 1.17$ (t, $J=7.5 \mathrm{~Hz}, 9 \mathrm{H}), 0.95(\mathrm{q}, J=7.5 \mathrm{~Hz}, 6 \mathrm{H}) ;{ }^{31} \mathrm{P}\left\{{ }^{1} \mathrm{H}\right\} \mathrm{NMR}(\mathrm{THF}) \delta 53.1(\mathrm{~d}, J=26 \mathrm{~Hz}), 40.2$ $(\mathrm{d}, J=26 \mathrm{~Hz}) .{ }^{11} \mathrm{~B}$ NMR $\left(\mathrm{C}_{6} \mathrm{D}_{6}\right) \delta$-0.01. Anal. Calcd. For $\mathrm{C}_{53} \mathrm{H}_{61} \mathrm{BN}_{2} \mathrm{O}_{2} \mathrm{P}_{2} \mathrm{PdS}: \mathrm{C}, 65.67 ; \mathrm{H}, 6.34 ; \mathrm{N}, 2.89$. Found: C, 65.47; H, 6.28; N, 2.77. 


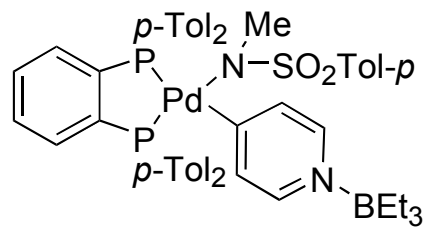

Reductive Elimination Reactions. A typical procedure is provided for reaction of $\left[\mathrm{Pd}(\mathrm{DPPBz})\left(\mathrm{C}_{5} \mathrm{H}_{4} \mathrm{~N}-\right.\right.$ $\left.\left.\mathrm{C}^{2}\right)\left(\mathrm{N}\left(\mathrm{C}_{6} \mathrm{H}_{4}-4-t-\mathrm{Bu}\right)_{2}\right)\right]$ complex 8. Into an NMR tube with a Teflon-lined screw-cap was placed $0.5 \mathrm{ml}$ of a $\mathrm{C}_{6} \mathrm{D}_{6}$ solution containing complex $8(9.0 \mathrm{mg}, 0.010 \mathrm{mmol}), \mathrm{PPh}_{3}(39.4 \mathrm{mg}, 0.150 \mathrm{mmol})$, and trimethoxybenzene $\left(10 \mu \mathrm{L}, 0.5 \mathrm{M}\right.$ in $\left.\mathrm{C}_{6} \mathrm{D}_{6}\right)$. A ${ }^{1} \mathrm{H}$ NMR spectrum was obtained of this initial mixture. The tube was then placed in an oil bath at $70{ }^{\circ} \mathrm{C}$ for $5 \mathrm{~h}$, after which time ${ }^{1} \mathrm{H}$ NMR spectroscopy showed the formation of reductive elimination product in $95 \%$ yield. The yield of reductive elimination product was determined by integrating the methyl resonances of the palladium complex and the methyl protons of the triarylamine with respect to the internal standard. Yields for reactions of the other amido and sulfonamido complexes are provided in the tables of the body of the paper.

Measurement of the Rate Constants for Reductive Elimination in the Presence of Lewis Acids: Representative Procedure for Isolated Complex with Lewis Acid. Into an NMR tube with a Teflon-lined screw-cap was placed $0.5 \mathrm{ml}$ of a toluene- $d_{8}$ solution containing complex $13(9.7 \mathrm{mg}, 0.010 \mathrm{mmol}), \mathrm{P}\left(\mathrm{Ph}-d_{5}\right)_{3}$ (27 mg, $0.10 \mathrm{mmol})$, and trimethoxybenzene $\left(10 \mu \mathrm{L}, 0.5 \mathrm{M}\right.$ in toluene- $\left.d_{8}\right)$. The sample was heated at $90{ }^{\circ} \mathrm{C}$, and ${ }^{1} \mathrm{H}$ NMR spectra were obtained every $5 \mathrm{~min}$ for at least 5 half-lives by an automated acquisition program.

Representative Procedure for Reductive Eliminations with Added Lewis Acid. Into an NMR tube with a Teflon-lined screw-cap was placed $0.5 \mathrm{ml}$ of a toluene- $d_{8}$ solution containing complex 11 (9.0 mg, 0.010 $\mathrm{mmol})$ and $\mathrm{BPh}_{3}(1.5 \mathrm{mg}, 0.010 \mathrm{mmol})$. The solid gradually dissolved to give a clear pale pink solution. $\mathrm{P}\left(\mathrm{Ph}-d_{5}\right)_{3}(27 \mathrm{mg}, 0.10 \mathrm{mmol})$, and trimethoxybenzene $\left(10 \mu \mathrm{L}, 0.5 \mathrm{M}\right.$ in toluene- $\left.d_{8}\right)$ were then added. The sample was heated at $70{ }^{\circ} \mathrm{C}$, and ${ }^{1} \mathrm{H}$ NMR spectra were obtained every $5 \mathrm{~min}$ for at least 5 half-lives by an automated acquisition program.

Independent Synthesis of the Products from Reductive Elimination.

General Procedure for the Preparation of 2-(Di-p-t-butylphenylamino)pyridine. A typical procedure is given for the preparation of $N, N$-di- $p$-t-butylphenyl-amino-2-pyridine.

2-(Di-p-t-butylphenylamino)pyridine. Into a $20 \mathrm{~mL}$ Schlenk tube was placed $\mathrm{Pd}(\mathrm{dba})_{2}(12 \mathrm{mg}, 0.020$ mmol), BINAP (25 mg, $0.040 \mathrm{mmol}), \mathrm{NaO} t \mathrm{Bu}(58 \mathrm{mg}, 0.60 \mathrm{mmol})$, and di- $p$ - $t$-butylphenylamine $(169 \mathrm{mg}$, $0.600 \mathrm{mmol}$ ). The tube was sealed with septum and then evacuated and filled with nitrogen three times. 2Bromopyridine $(79.0 \mathrm{mg}, 0.500 \mathrm{mmol})$ and toluene $(10 \mathrm{~mL})$ were then added. The reaction mixture was stirred for $12 \mathrm{~h}$ at $70{ }^{\circ} \mathrm{C}$. The reaction mixture was allowed to cool to room temperature before filtered through a short plug of Celite. The solvent was evaporated, and the crude product isolated by eluting with hexane/ethyl acetate $(95 / 5)$ to give $155 \mathrm{mg}(87 \%)$ of the product as a white solid. ${ }^{1} \mathrm{H} \mathrm{NMR}\left(\mathrm{C}_{6} \mathrm{D}_{6}\right) \delta 8.20(\mathrm{~d}$, $J=4.8 \mathrm{~Hz}, 1 \mathrm{H}), 7.24(\mathrm{~d}, J=8.8 \mathrm{~Hz}, 4 \mathrm{H}), 7.20(\mathrm{~d}, J=8.4 \mathrm{~Hz}, 4 \mathrm{H}), 6.97$ (ddd, $J=8.0,7.2,2.0 \mathrm{~Hz}, 1 \mathrm{H})$, $6.69(\mathrm{~d}, J=8.4 \mathrm{~Hz}, 1 \mathrm{H}), 6.39(\mathrm{dd}, J=7.2,4.8 \mathrm{~Hz}, 1 \mathrm{H}), 1.20(\mathrm{~s}, 18 \mathrm{H}) ;{ }^{13} \mathrm{C} \mathrm{NMR}\left(\mathrm{C}_{6} \mathrm{D}_{6}\right) \delta 159.57,148.45$, 147.18, 144.18, 136.88, 126.81, 126.40, 115.50, 112.65, 34.34, 31.46. Anal. Calcd. For $\mathrm{C}_{25} \mathrm{H}_{30} \mathrm{~N}_{2}$ : C, 83.75; H, 8.43; N, 7.81. Found: C, 83.68; H, 8.47; N, 7.58. 


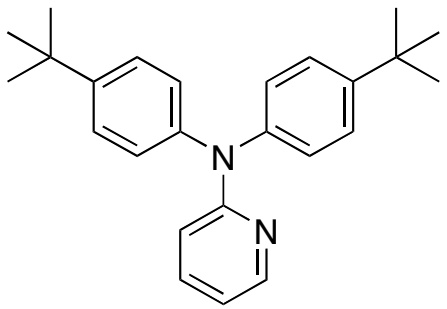

3-(Di-p-t-butylphenylamino)pyridine. The general procedure was followed to give $128 \mathrm{mg}$ (72\%) of the product. ${ }^{1} \mathrm{H} \mathrm{NMR}\left(\mathrm{C}_{6} \mathrm{D}_{6}\right) \delta 8.72(\mathrm{~d}, J=2.4 \mathrm{~Hz}, 1 \mathrm{H}), 8.24(\mathrm{dd}, J=4.8,1.2 \mathrm{~Hz}, 1 \mathrm{H}), 7.14(\mathrm{~d}, J=8.4 \mathrm{~Hz}, 4$ $\mathrm{H}), 7.10-7.13(\mathrm{~m}, 1 \mathrm{H}), 7.02(\mathrm{~d}, J=8.4 \mathrm{~Hz}, 4 \mathrm{H}), 6.65(\mathrm{dd}, J=8.4,4.8 \mathrm{~Hz}, 1 \mathrm{H}), 1.21(\mathrm{~s}, 18 \mathrm{H}) ;{ }^{13} \mathrm{C} \mathrm{NMR}$ $\left(\mathrm{C}_{6} \mathrm{D}_{6}\right) \delta 146.43,145.24,144.95,144.84,142.99,128.53,126.70,124.58,123.48,34.28,31.45$. Anal. Calcd. For $\mathrm{C}_{25} \mathrm{H}_{30} \mathrm{~N}_{2}$ : C, 83.75; H, 8.43; N, 7.81. Found: C, 83.69; H, 8.46; N, 7.58.<smiles>CC(C)(C)c1ccc(N(c2ccc(C(C)(C)C)cc2)c2cccnc2)cc1</smiles>

4-(Di-p-t-butylphenylamino)pyridine. The general procedure was followed to give $135 \mathrm{mg}(\mathbf{7 6 \%})$ of the product. ${ }^{1} \mathrm{H} \mathrm{NMR}\left(\mathrm{CDCl}_{3}\right) \delta 8.17(\mathrm{dd}, J=6.0,1.5 \mathrm{~Hz}, 2 \mathrm{H}), 7 .(\mathrm{d}, J=7.2, \mathrm{~Hz}, 4 \mathrm{H}), 7.10(\mathrm{~d}, J=7.2 \mathrm{~Hz}, 4$ $\mathrm{H}), 6.67(\mathrm{dd}, J=4.5,1.5 \mathrm{~Hz}, 2 \mathrm{H}), 1.30(\mathrm{~s}, 18 \mathrm{H}) ;{ }^{13} \mathrm{C} \mathrm{NMR}\left(\mathrm{CDCl}_{3}\right) \delta 153.84,150.0,148.49,142.33$, 126.57, 126.24, 111.94, 34.45, 31.31. Anal. Calcd. For $\mathrm{C}_{25} \mathrm{H}_{30} \mathrm{~N}_{2}$ : C, 83.75; H, 8.43; N, 7.81. Found: C, $83.56 ; \mathrm{H}, 8.63 ; \mathrm{N}, 7.68$.<smiles>CC(C)(C)c1ccc(N(c2ccncc2)c2ccc(C(C)(C)C)cc2)cc1</smiles>

General Procedure for the Preparation of $N$-4-Pyridyl- $N$-Methylsulfonamine. A typical procedure is given for the preparation of $N$-4-Pyridyl- $N$-Methyl-p-tolylsulfonylamine.

$N$-4-Pyridyl- $N$-Methyl-p-toluenesulfonamine. Into a small round bottom flask was placed 4(dimethylamino)pyridine $(10 \mathrm{mg}, 0.082 \mathrm{mmol})$, 4-(methylamino)pyridine (108 $\mathrm{mg}, 1.00 \mathrm{mmol})$ and $p$ toluenesulfonyl chloride $(191 \mathrm{mg}, 1.00 \mathrm{mmol})$. Pyridine $(2.0 \mathrm{~mL})$ was then added. The reaction mixture was stirred for $18 \mathrm{~h}$ at $60{ }^{\circ} \mathrm{C}$. The reaction mixture was allowed to cool to room temperature before the solvent was evaporated. The crude product was isolated by silica gel chromatography eluting with ethyl acetate to give $236 \mathrm{mg}(90 \%)$ of the product as a pale yellow liquid. ${ }^{1} \mathrm{H}$ NMR $\left(\mathrm{C}_{6} \mathrm{D}_{6}\right) \delta 8.49(\mathrm{~d}, J=4.3 \mathrm{~Hz}, 2 \mathrm{H}), 7.44$ $(\mathrm{d}, J=7.5 \mathrm{~Hz}, 2 \mathrm{H}), 7.23(\mathrm{~d}, J=8.0 \mathrm{~Hz}, 2 \mathrm{H}), 7.14(\mathrm{dd}, J=4.5,1.5 \mathrm{~Hz}, 2 \mathrm{H}), 3.20(\mathrm{~s}, 3 \mathrm{H}), 2.38(\mathrm{~s}, 3 \mathrm{H}) .{ }^{13} \mathrm{C}$ NMR $\left(\mathrm{CDCl}_{3}\right) \delta 150.20,148.58,144.18,133.05,129.49,127.10,117.64,36.06,21.24$. Anal. Calcd. For $\mathrm{C}_{10} \mathrm{H}_{14} \mathrm{~N}_{2} \mathrm{O}_{2} \mathrm{~S}$ : C, 59.52; H, 5.38; N, 10.68. Found: C, 59.29; H, 5.54; N, 10.45 . 


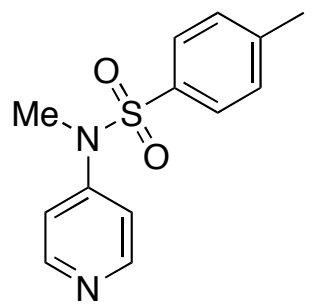

$\boldsymbol{N}$-4-Pyridyl- $\boldsymbol{N}$-Methyl-benzenesulfonamine. The general procedure was followed to give $211 \mathrm{mg}(85 \%)$ of the product as a pale yellow liquid ${ }^{1} \mathrm{H}$ NMR $\left(\mathrm{CDCl}_{3}\right) \delta 8.49(\mathrm{dd}, J=5.0,1.5 \mathrm{~Hz}, 2 \mathrm{H}), 7.55-7.60(\mathrm{~m}, 3 \mathrm{H})$, $7.44(\mathrm{t}, J=7.5 \mathrm{~Hz}, 2 \mathrm{H}), 7.13(\mathrm{dd}, J=5.0,1.5 \mathrm{~Hz}, 2 \mathrm{H}), 3.21(\mathrm{~s}, 3 \mathrm{H}) ;{ }^{13} \mathrm{C} \mathrm{NMR}\left(\mathrm{CDCl}_{3}\right) \delta 150.58,148.75$, 136.26, 133.40, 129.09, 127.36, 118.53, 36.38. Anal. Calcd. For $\mathrm{C}_{12} \mathrm{H}_{12} \mathrm{~N}_{2} \mathrm{O}_{2} \mathrm{~S}$ : C, 58.05; H, 4.37; N, 11.28. Found: C, 58.42; H, 4.77; N, 10.94 .<smiles>CN(c1ccncc1)S(=O)(=O)c1ccccc1</smiles>

General Procedure for the Palladium-Catalyzed Amidation of Heteroaryl Halides in the Presence of Lewis Acids. A typical procedure is given for the preparation of $N$-3-pyridyl-pyrrolidinone.

$N$-3-Pyridyl-pyrrolidinone. A $1.0 \mathrm{M}$ solution of $\mathrm{BEt}_{3}$ in hexane $(1.0 \mathrm{~mL}, 1.0 \mathrm{mmol})$ was added dropwise to a solution of 3-bromopyridine $(158 \mathrm{mg}, 1.00 \mathrm{mmol})$ in diethyl ether $(2.0 \mathrm{~mL})$. The mixture was stirred for 2 $\mathrm{h}$ at room temperature. The solvent was then evaporated under vacuum. Toluene $(1.0 \mathrm{~mL})$ was added. The toluene solution was added to a vial placed $\mathrm{Pd}(\mathrm{dba})_{2}(11.6 \mathrm{mg}, 0.020 \mathrm{mmol})$, Xantphos $(11.8 \mathrm{mg}, 0.020$ $\mathrm{mmol}), \mathrm{K}_{3} \mathrm{PO}_{4}(254 \mathrm{mg}, 1.20 \mathrm{mmol})$, pyrrolidinone $(102 \mathrm{mg}, 1.20 \mathrm{mmol})$. The vial was sealed with a cap containing a PTFE septum, and the mixture was stirred at $110{ }^{\circ} \mathrm{C}$ for $24 \mathrm{~h}$ until the 3-bromopyridine was consumed, as determined by GC/MS. The reaction mixture was allowed to cool to room temperature. After filtration and evaporation of the solvent, the residue was purified by chromatography on silica gel (ethyl acetate/methanol $=90 / 10)$ to give $136 \mathrm{mg}(84 \%)$ of $\mathrm{N}$-3-pyridyl-pyrrolidinone as a white solid. ${ }^{1} \mathrm{H}$ NMR $\left(\mathrm{CDCl}_{3}\right) \delta 8.64(\mathrm{~d}, J=2.5 \mathrm{~Hz}, 1 \mathrm{H}), 8.29(\mathrm{dd}, J=5.0,1.5 \mathrm{~Hz}, 1 \mathrm{H}), 7.42(\mathrm{ddd}, J=8.5,2.5,1.5 \mathrm{~Hz}, 1 \mathrm{H}), 7.20$ $(\mathrm{dd}, J=8.5,5.0 \mathrm{~Hz}, 1 \mathrm{H}), 3.80(\mathrm{t}, J=7.5 \mathrm{~Hz}, 2 \mathrm{H}), 2.53(\mathrm{t}, J=7.5 \mathrm{~Hz}, 2 \mathrm{H}), 2.12$ (quint, $J=7.5 \mathrm{~Hz}, 2 \mathrm{H}$ ); ${ }^{13} \mathrm{C} \mathrm{NMR}\left(\mathrm{CDCl}_{3}\right) \delta 174.62,145.14,145.36,135.86,126.67,123.20,47.71,32.12,17.80$.<smiles>O=C1CCCN1c1cccnc1</smiles>

$N$-3-Pyridylbenzamide. The general procedure, eluting with ethyl acetate/methanol = 90/10, gave $147 \mathrm{mg}$ (74\%) of the product as a pale yellow liquid ${ }^{1} \mathrm{H}$ NMR (DMSO- $\left.d 6\right) \delta 10.46(\mathrm{~s}, 1 \mathrm{H}), 8.93(\mathrm{~s}, 1 \mathrm{H}), 8.30(\mathrm{~d}, J=$ $1.5 \mathrm{~Hz}, 1 \mathrm{H}), 8.19$ (d, $J=7.5 \mathrm{~Hz}, 1 \mathrm{H}), 7.96(\mathrm{~d}, J=8.0 \mathrm{~Hz}, 2 \mathrm{H}), 7.59(\mathrm{~d}, J=7.0 \mathrm{~Hz}, 1 \mathrm{H}), 7.53(\mathrm{t}, J=7.5$ $\mathrm{Hz}, 2 \mathrm{H}), 7.37$ (dd, $J=8.0,4.5 \mathrm{~Hz}, 1 \mathrm{H}) ;{ }^{13} \mathrm{C}$ NMR (DMSO-d6) $\delta 166.03,144.65,142.04,135.89,134.41$, $131.97,128.55,127.80,127.35,123.61$.<smiles>O=C(Nc1cccnc1)c1ccccc1</smiles> 
$\boldsymbol{N}$-4-Pyridyl- $\boldsymbol{N}$-Methyl-benzenesulfonamine. The general procedure, eluting with ethyl acetate, gave 239 $\mathrm{mg}(91 \%)$ of the product as a pale yellow liquid. ${ }^{1} \mathrm{H}$ NMR $\left(\mathrm{C}_{6} \mathrm{D}_{6}\right) \delta 8.49(\mathrm{~d}, J=4.3 \mathrm{~Hz}, 2 \mathrm{H}), 7.44(\mathrm{~d}, J=7.5$ $\mathrm{Hz}, 2 \mathrm{H}), 7.23(\mathrm{~d}, J=8.0 \mathrm{~Hz}, 2 \mathrm{H}), 7.14(\mathrm{dd}, J=4.5,1.5 \mathrm{~Hz}, 2 \mathrm{H}), 3.20(\mathrm{~s}, 3 \mathrm{H}), 2.38(\mathrm{~s}, 3 \mathrm{H}) .{ }^{13} \mathrm{C} \mathrm{NMR}$ $\left(\mathrm{CDCl}_{3}\right) \delta 150.20,148.58,144.18,133.05,129.49,127.10,117.64,36.06,21.24$. Anal. Calcd. For $\mathrm{C}_{10} \mathrm{H}_{14} \mathrm{~N}_{2} \mathrm{O}_{2} \mathrm{~S}: \mathrm{C}, 59.52 ; \mathrm{H}, 5.38 ; \mathrm{N}, 10.68$. Found: C, 59.29; H, 5.54; N, 10.45 .

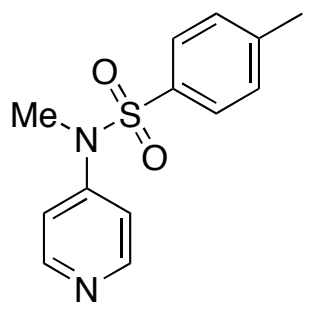

$N$-4-Pyridyl-valerolactam. The general procedure, eluting with ethyl acetate/methanol $=80 / 20$, gave 155 $\mathrm{mg}(88 \%)$ of the product as a white solid. ${ }^{1} \mathrm{H} \mathrm{NMR}\left(\mathrm{CDCl}_{3}\right) \delta 8.56(\mathrm{~d}, J=5.0 \mathrm{~Hz}, 2 \mathrm{H}), 7.29(\mathrm{~d}, J=5.0 \mathrm{~Hz}, 2$ $\mathrm{H}), 3.68(\mathrm{t}, J=6.0 \mathrm{~Hz}, 2 \mathrm{H}), 2.57(\mathrm{t}, J=6.5 \mathrm{~Hz}, 2 \mathrm{H}), 1.89-1.98(\mathrm{~m}, 4 \mathrm{H}) ;{ }^{13} \mathrm{C} \mathrm{NMR}\left(\mathrm{CDCl}_{3}\right) \delta 170.15$, 150.45, 150.08, 118.93, 49.82, 33.24, 23.21, 21.04. Anal. Calcd. For $\mathrm{C}_{10} \mathrm{H}_{12} \mathrm{~N}_{2} \mathrm{O}: \mathrm{C}, 68.16 ; \mathrm{H}, 6.86 ; \mathrm{N}, 15.90$. Found: C, 67.88; H, 6.82; N, 15.88 .

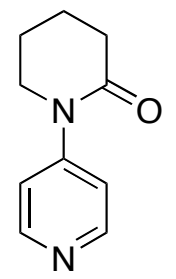

N-3-Pyrimidinyl-pyrrolidinone. Following the above procedure (ethyl acetate/methanol $=90 / 10)$ to give 92 $\mathrm{mg}(57 \%)$ of the product as a white sold. ${ }^{1} \mathrm{H} \mathrm{NMR}\left(\mathrm{CDCl}_{3}\right) \delta 9.04(\mathrm{~s}, 2 \mathrm{H}), 8.91(\mathrm{~s}, 1 \mathrm{H}), 3.83(\mathrm{t}, J=7.0 \mathrm{~Hz}$, $2 \mathrm{H}$ ), $2.58(\mathrm{t}, J=8.0 \mathrm{~Hz}, 2 \mathrm{H}), 2.12$ (quint, $J=7.5 \mathrm{~Hz}, 2 \mathrm{H}) ;{ }^{13} \mathrm{C}$ NMR $\left(\mathrm{CDCl}_{3}\right) \delta 174.87,153.79,146.70$, 134.49, 46.77, 31.71, 17.97. Anal. Calcd. For $\mathrm{C}_{8} \mathrm{H}_{9} \mathrm{~N}_{3} \mathrm{O}$ : C, 58.88; H, 5.56; N, 25.75. Found: C, 59.16; H, $5.41 ; \mathrm{N}, 25.48$.<smiles>O=C1CCCN1c1cncnc1</smiles>

Procedure for the Palladium-Catalyzed Amidation of Heteroaryl Halides in the Presence of Catalytic Amount of the Lewis Acids. Into a vial was added 3-bromopyridine (0.126 mg, $0.800 \mathrm{mmol})$ and 3bromopyridine triethylborane complex $(52.0 \mathrm{mg}, 0.200 \mathrm{mmol})$ and pyrrolidinone $(102 \mathrm{mg}, 1.20 \mathrm{mmol})$. $\mathrm{Pd}(\mathrm{dba})_{2}$ (11.6 mg, $\left.0.020 \mathrm{mmol}\right)$, Xantphos (11.8 mg, $\left.0.020 \mathrm{mmol}\right), \mathrm{K}_{3} \mathrm{PO}_{4}(254 \mathrm{mg}, 1.20 \mathrm{mmol})$ were then added, followed by toluene $(1.0 \mathrm{ml})$ and the stirring bar. The vial was sealed with a cap containing a PTFE septum, and the mixture was stirred at $110{ }^{\circ} \mathrm{C}$ for $1.5 \mathrm{~h}$ until the 3-bromopyridine was consumed, as determined by GC/MS. The reaction mixture was allowed to cool to room temperature. After filtration and evaporation of the solvent, the residue was purified by chromatography on silica gel (ethyl acetate/methanol $=90 / 10)$ to give $133 \mathrm{mg}(83 \%)$ of $N$-3-pyridyl-pyrrolidinone as a white solid.<smiles>O=C1CCCN1c1cccnc1</smiles> 


\section{References:}

1. (a) Isobe, K.; Nanjo, K.; Nakamura, Y.; Kawaguchi, S. Bull. Chem. Soc. Jpn. 1986, 59, 2141. (b) Isobe, K.; Nanjo, K.; Nakamura, Y.; Kawaguchi, S. Bull. Chem. Soc. Jpn. 1986, 60, 149.

2. Culkin, D. A.; Hartwig, J. F. Organometallics 2004. 23, 3398-3416. 
(1)
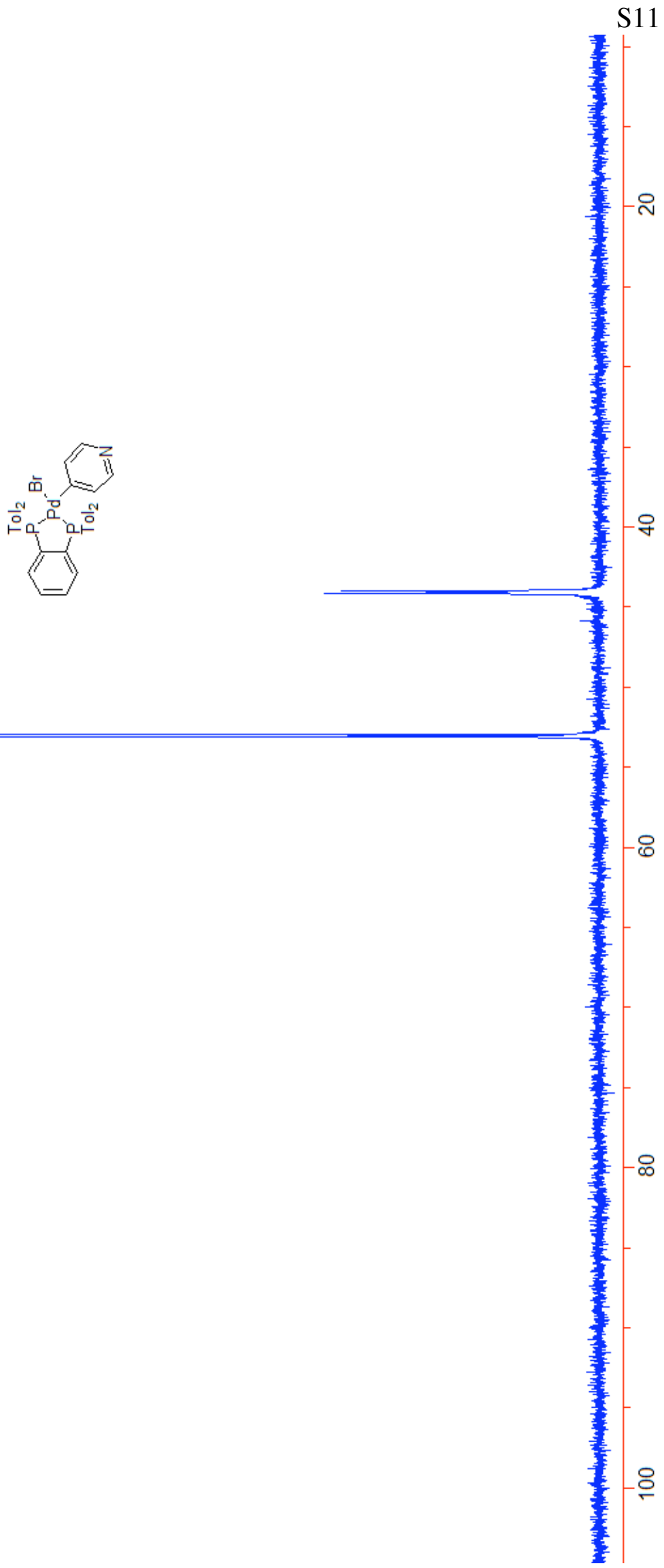
(2)

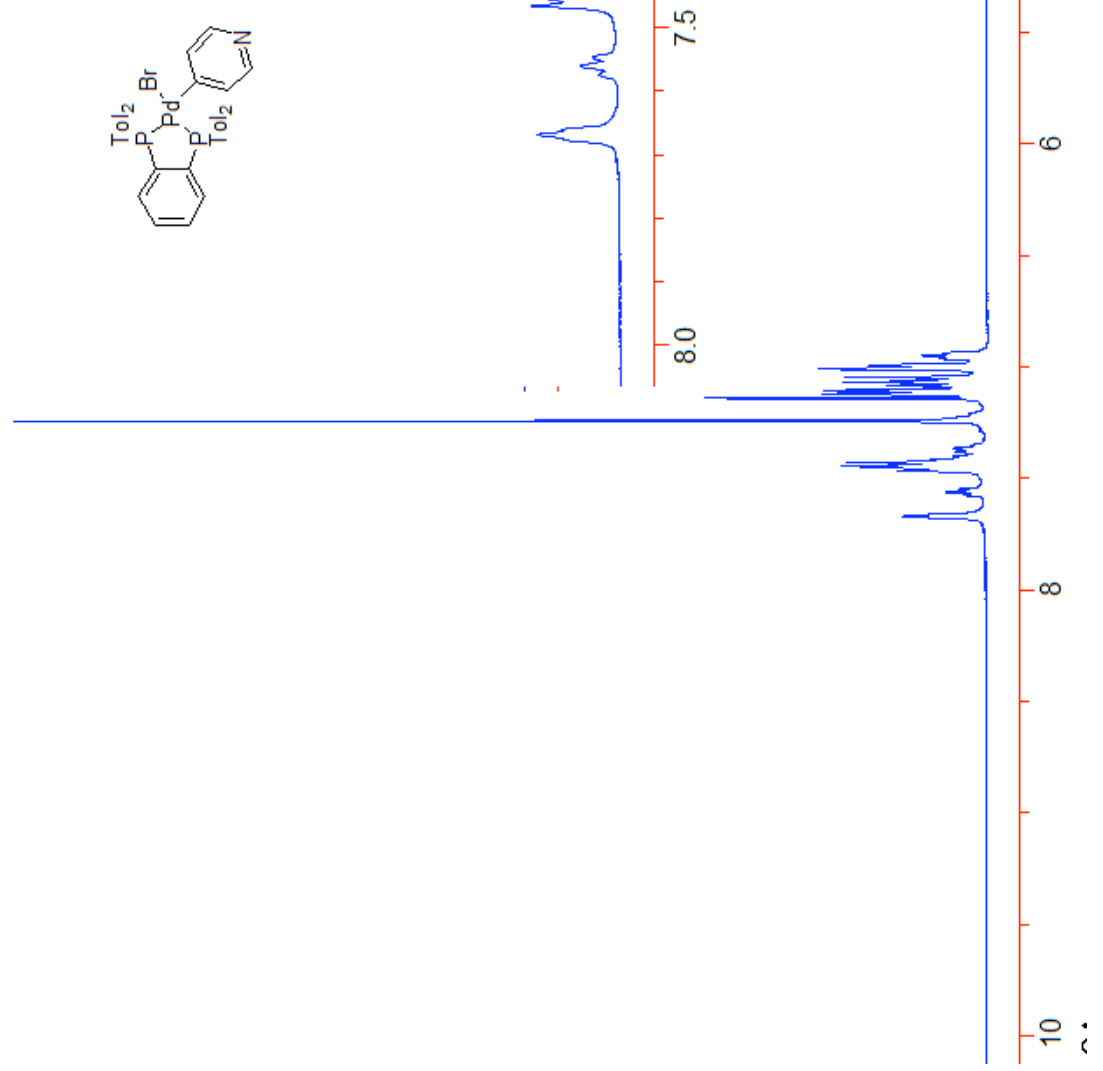




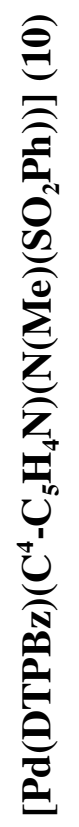
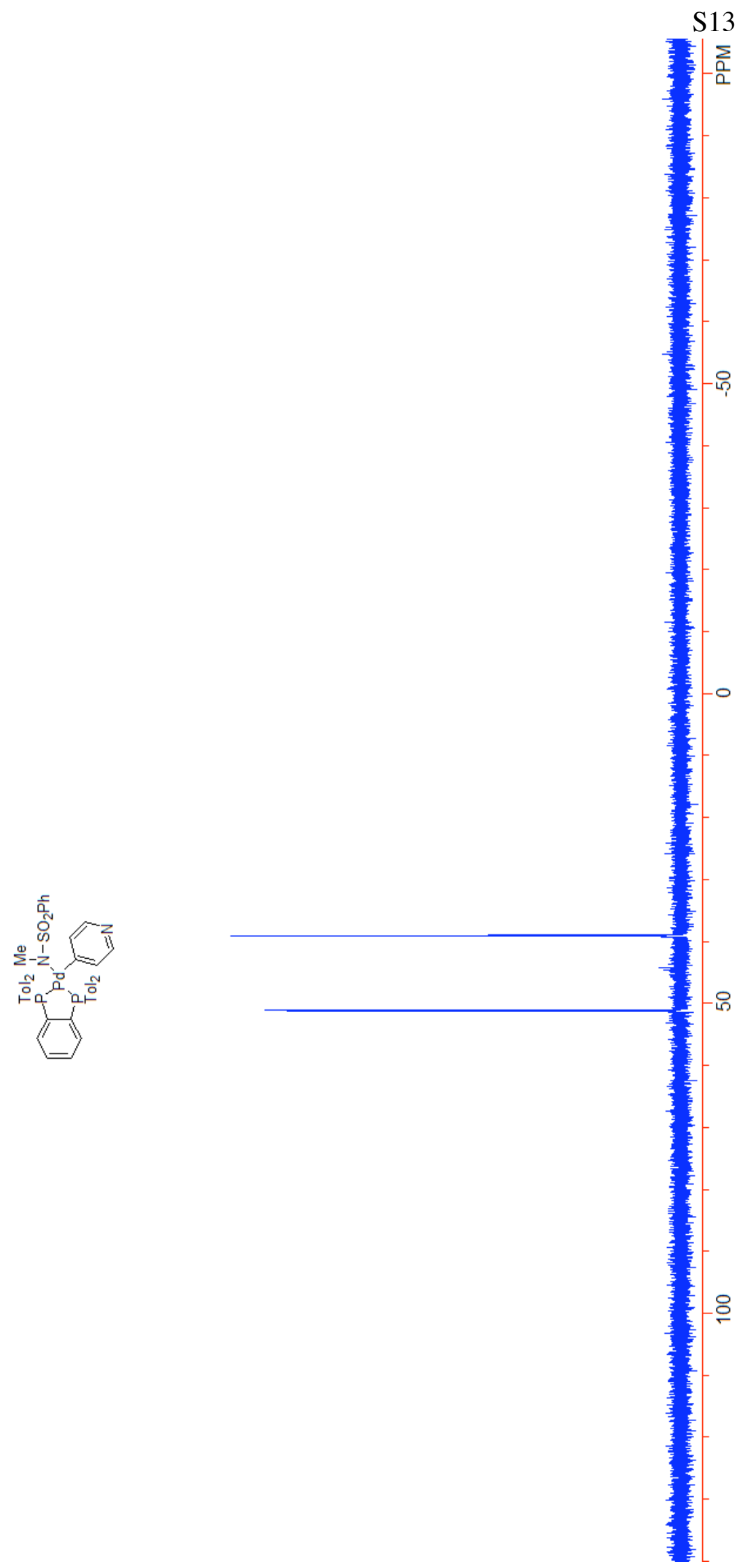

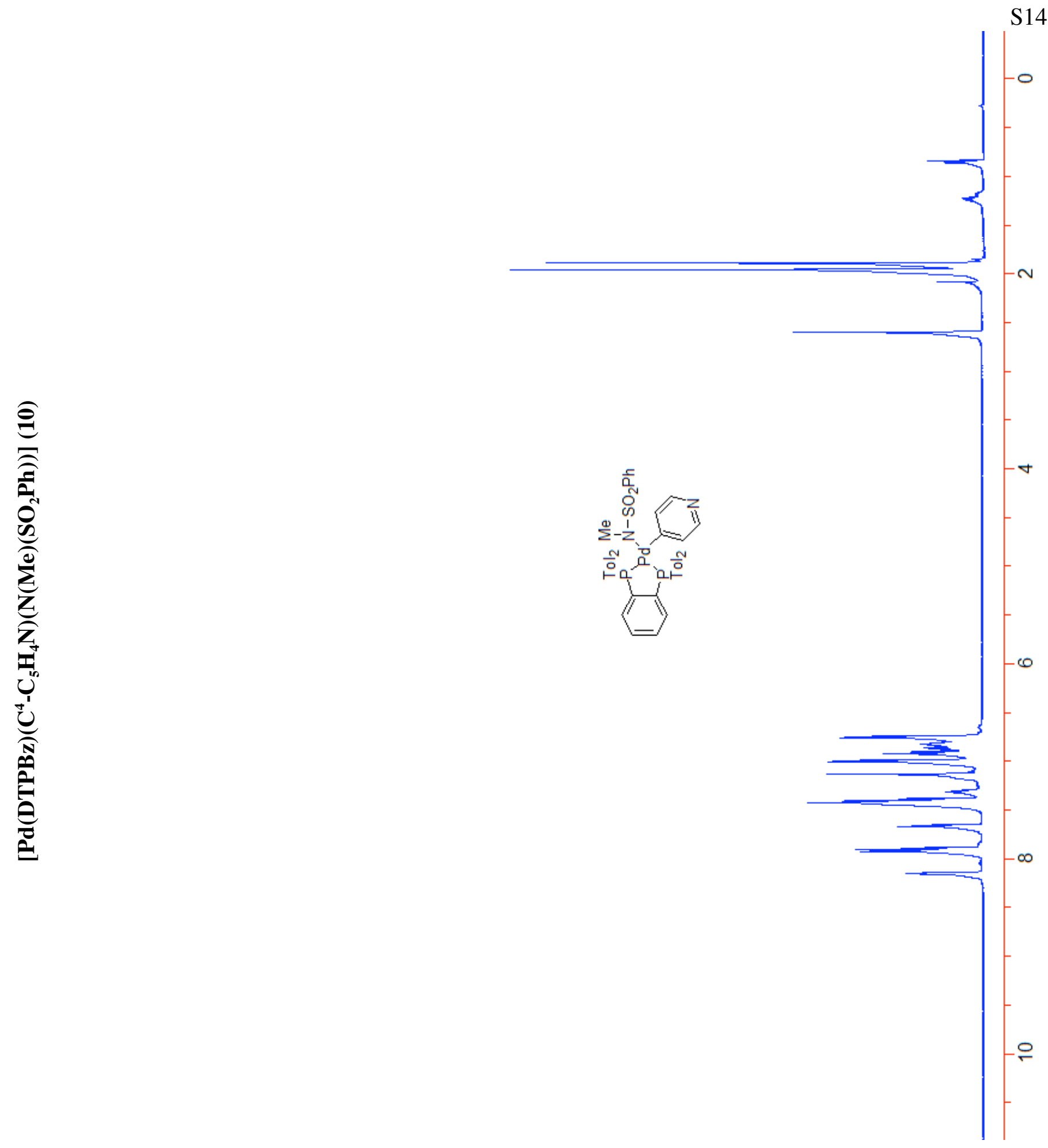

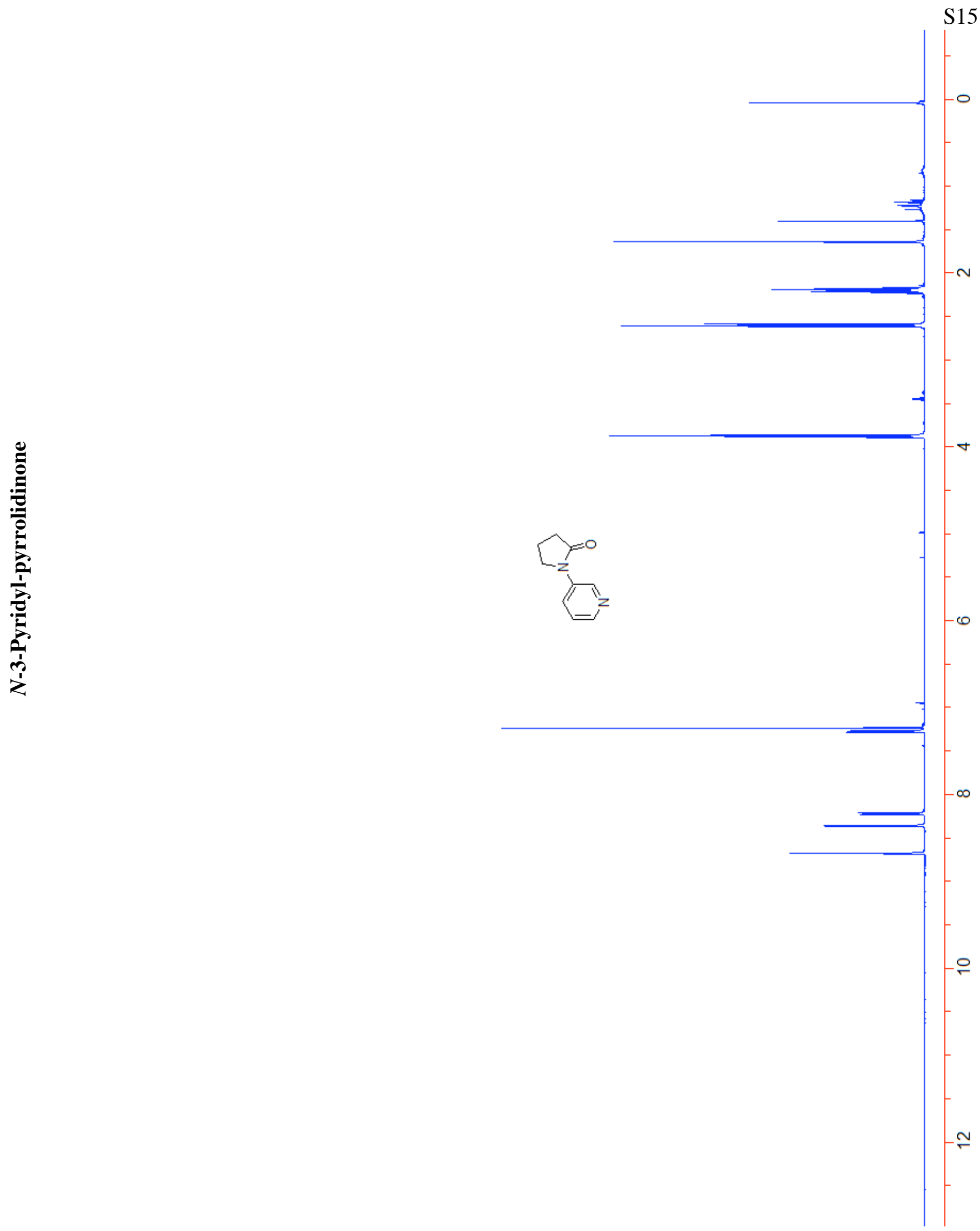

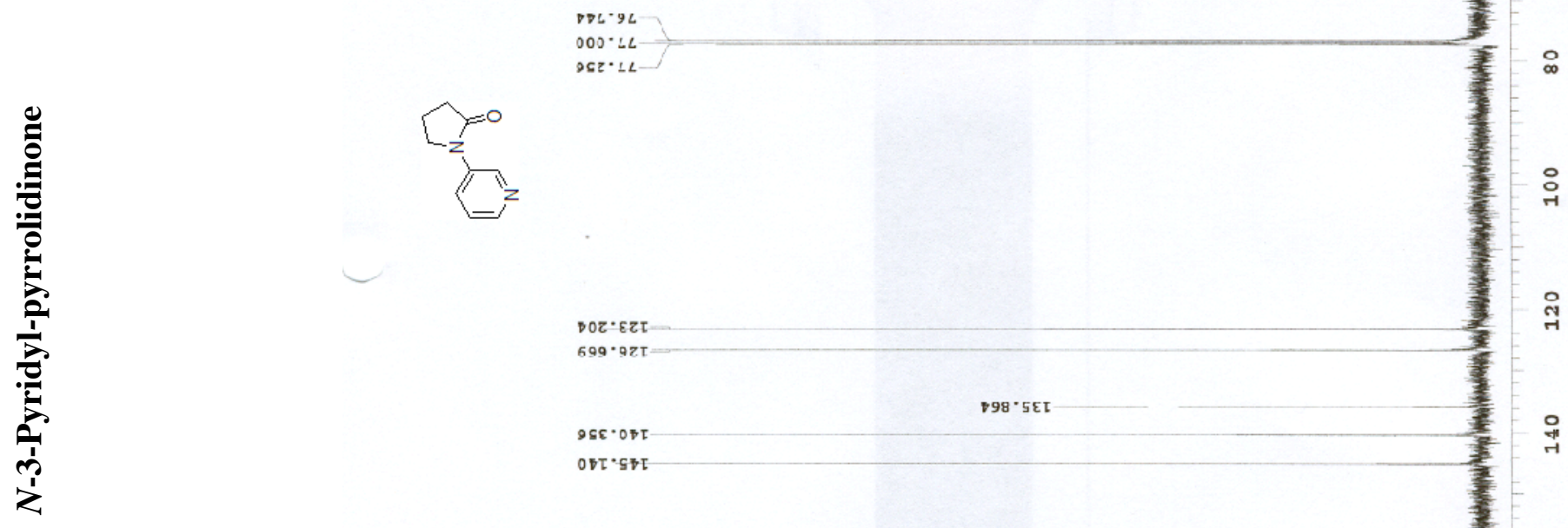

$B T L \cdot \angle F$

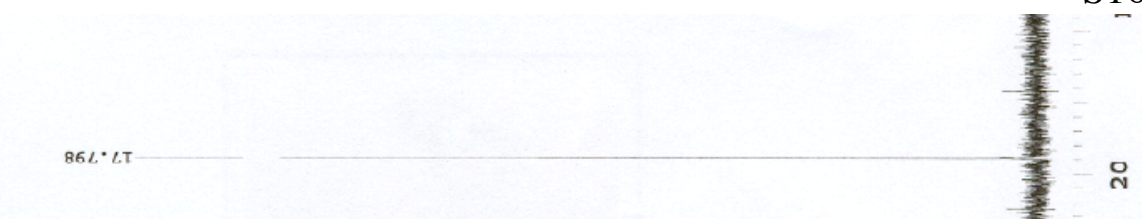

$\frac{3}{3}$
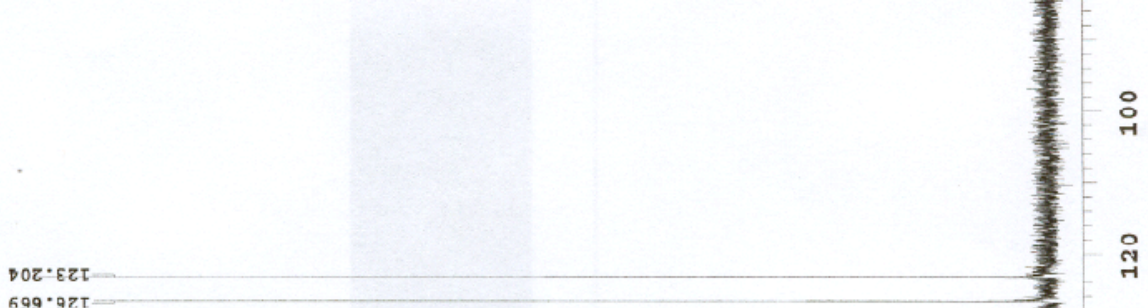

9sE. ODL

$0 \nabla \tau \cdot \mathrm{T} T$

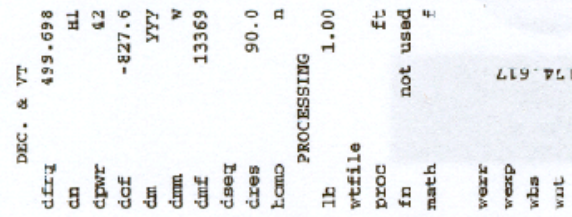

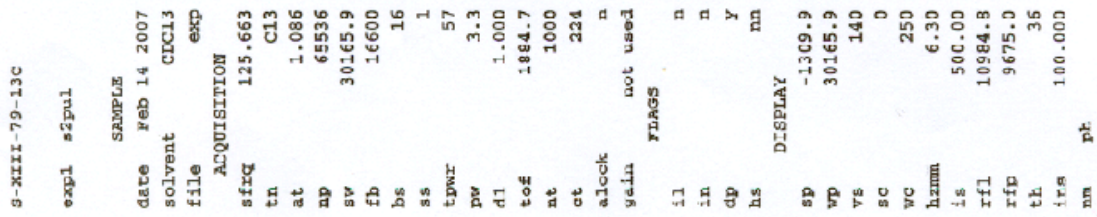

